\title{
Article
}

\section{Palladium-Nanoparticles Biohybrids in Applied Chemistry}

\author{
Marco Filice ${ }^{1,+}$, Noelia Losada-Garcia ${ }^{1}$ (D), Carlos Perez-Rizquez ${ }^{1}$ (D), Marzia Marciello ${ }^{2,+}$, \\ Maria del Puerto Morales ${ }^{2}$ and Jose M. Palomo ${ }^{1, *(D)}$
}

1 Department of Biocatalysis, Institute of Catalysis (ICP-CSIC), Marie Curie 2, Cantoblanco, Campus UAM, 28049 Madrid, Spain; m.filice@icp.csic.es or mfilice@ucm.es (M.F.); n.losada@csic.es (N.L.-G.); c.p.rizquez@csic.es (C.P.-R.)

2 Department of Energy, Environment and Health, Institute of Material Science of Madrid (ICMM-CSIC), Sor Juana Ines de la Cruz 3, 28049 Madrid, Spain; marmarci@ucm.es or m.marciello@icmm.csic.es (M.M.); puerto@icmm.csic.es (M.d.P.M.)

* Correspondence: josempalomo@icp.csic.es; Tel.: +34-9158-5476-8

+ Current address: Department of Chemistry in Pharmaceutical Sciences, Faculty of Pharmacy, Complutense University (UCM), Plaza Ramón y Cajal, 28040 Madrid, Spain.

\begin{abstract}
Applied nanotechnology has experienced tremendous advance over the last decade. In this study, the efficient synthesis of highly stable palladium-nanoparticles (PdNPs) biohybrids based on the application of an enzyme, which induces in situ the generation of spherical nanoparticles on the protein network, has been described. A heterogeneous material was synthesized formed with PdNPs with average sizes between 1.5 to $5 \mathrm{~nm}$. These Pd nanocatalysts were successfully applied in different chemical processes: C-C bonding reactions (Suzuki and Heck reactions) and cascade processes combining enzymatic and metallic activities (hydrolysis-reduction, esterification-racemization).
\end{abstract}

Keywords: palladium-nanoparticles; biohybrids; heterogeneous catalysis

Citation: Filice, M.; Losada-Garcia, N.; Perez-Rizquez, C.; Marciello, M.; Morales, M.d.P.; Palomo, J.M. Palladium-Nanoparticles Biohybrids in Applied Chemistry. Appl. Nano 2021, 2, 1-13. https://doi.org/ 10.3390/applnano2010001

Received: 5 November 2020 Accepted: 15 December 2020 Published: 29 December 2020

Publisher's Note: MDPI stays neutral with regard to jurisdictional clai$\mathrm{ms}$ in published maps and institutional affiliations.

Copyright: $(\odot 2020$ by the authors. Licensee MDPI, Basel, Switzerland. This article is an open access article distributed under the terms and conditions of the Creative Commons Attribution (CC BY) license (https:// creativecommons.org/licenses/by/ $4.0 /)$.

\section{Introduction}

Palladium-nanoparticles (PdNPs) biohybrids have shown an important role in a widespread variety of chemical reactions [1-4]. The intrinsic properties of nanoparticleswith an extremely large surface-to-volume ratio-provided advantages as catalysts compared to bulk materials.

However, typical strategies for the transition metal nanoparticle syntheses require severe conditions, such as high T, pressure, flammable solvents, etc. [5]. Therefore, recently more simple, efficient, and sustainable synthetic strategies have been developed [6-11].

In this way, the use of biological agents as plants, microorganisms, or fungi have allowed synthesizing Pd nanoparticles by a green way. However, important parameters such as the localization or morphology of the nanoparticles are subject to the microorganism species, since mixtures of enzymes and proteins can be involved in the process, producing nanoparticles of dissimilar sizes [12].

Therefore, the most suitable scheme would be the use of proteins or enzymes directly [13-16]. Protein scaffolds could offer splendid metal coordination environments that encourage biomineralization procedures, allowing the control of dimension, particle growing, and avoiding nanoparticles aggregation [17-19].

Furthermore, using an enzyme, it could be possible to conjugate the activity of the metal nanoparticles with the enzymatic activity in a one-pot catalyst, being an additional advantage compared with other methods.

Here, we describe the synthesis of high stable heterogeneous Pd nanocatalysts (enzyme/PdNPs biohybrids), where NPs were created in situ from an aqueous solution containing an enzyme and a noble metal salt (Figure 1) [20]. Different enzymes, such as scaffolds, were tested evaluating their role in the metal reduction, stabilization of nanoparticles, and remaining biocatalytic activity. 


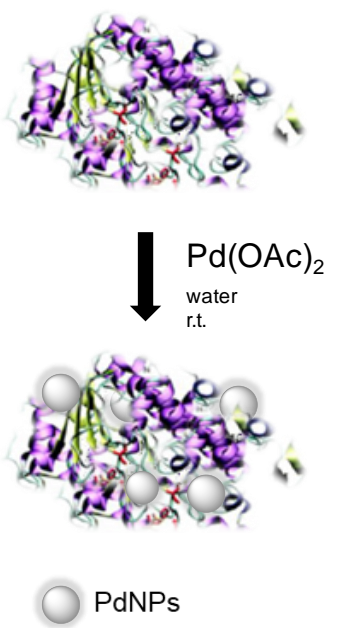

Figure 1. Palladium-nanoparticles biohybrid synthesis.

The enzyme operated at once as a reducing, stabilizing, and supporting mediator as well as a bio-catalyst. These novel biohybrids were effectively used as catalysts in several chemical reactions, $\mathrm{C}-\mathrm{C}$ bonding reaction, reductions, cascade processes in an aqueous or organic solvent as the reaction media, demonstrating their versatility as heterogeneous catalysts.

\section{Materials and Methods}

\subsection{Materials}

Candida antartica B lipase Lipozyme ${ }^{\circledR}$ CALB (CAL-B), Thermomyces lanuginose (TLL) Lipozyme $^{\circledR}$ TL 100 L, and Rhizomucor miehei lipase Palatase ${ }^{\circledR} 20,000$ L (Palatase) solutions were purchased from Novozymes (Bagsværd, Denmark). 4-Methoxybenzenediazonium tetrafluoroborate (MBDFB), p-nitrophenylpropionate ( $\mathrm{pNPP}), \mathrm{p}$-nitrophenol (pNP), p-aminophenol (pAP), bromobenzene, iodobenzene, chlorobenzene, phenylboronic acid, benzene, 4-metoxianisol, tetrabutylammonium fluoride (TBAF), tetrabutylammonium chloride ( $\mathrm{TBACl})$, tetrabutylammonium bromide (TBABr), ethyl acrylate, and palladium acetate were purchased from Sigma-Aldrich (now Merk, Darmstadt, Germany). N-AcetylL-tryptophan methyl ester (TrpOMe) was bought from Alfa Aesar (Shanghai, China).

\subsection{Characterization Techniques Used}

The TGA was performed with the EXSTAR 6300 (Seiko, Tokyo, Japan) equipment in a range of temperatures: $\mathrm{RT} / 1000{ }^{\circ} \mathrm{C}$. FTIR spectra were recorded on the FT-IR $20 \mathrm{SXC}$ (Nicolet) spectrophotometer.

The X-ray diffraction (XRD) pattern was acquired using a Texture Analysis Diffractometer D8 Advance (Bruker) with $\mathrm{Cu} \mathrm{K} \alpha$ radiation. The transmission electron microscopy (TEM) analysis was achieved on a JEOL 2100F microscope (Oxford Instruments, Oxford, UK). Inductively coupled plasma atomic emission spectrometry (ICP-OES) was performed on a Perkin Elmer OPTIMA 2100 DV equipment to determine the amount of Pd on the biohybrid. To recuperate the biohybrids, a Biocen $22 \mathrm{R}$ (Orto-Alresa, Spain) refrigerated centrifuge was employed. The HPLC spectrum P100 (Thermo Separation products) was used. The analyses were performed at $25{ }^{\circ} \mathrm{C}$ using an L-7300 column oven and a UV6000LP detector.

\subsection{Synthesis of PdNPs Biohybrids}

$\mathrm{Pd}(\mathrm{OAc})_{2}(50 \mathrm{mg})$ were dissolved in $10 \mathrm{~mL}$ of solvent $(\mathrm{DMF}, \mathrm{MeOH}$, or acetonitrile $(\mathrm{ACN})$ ). This solution was added to $40 \mathrm{~mL}$ of a distilled water solution containing $16 \mathrm{mg}$ of Cal-B protein $\left(1.6 \mathrm{~mL}\right.$ of commercial Lipozyme ${ }^{\circledR}$ CALB solution $\left(10 \mathrm{mg}\right.$ protein $\left.\cdot \mathrm{mL}^{-1}\right)$, $0.7 \mathrm{~mL}$ of Lipozyme ${ }^{\circledR}$ TL 100L $\left(24 \mathrm{mg} \cdot \mathrm{mL}^{-1}\right)$, or $2.7 \mathrm{~mL}$ of Palatase ${ }^{\circledR} 20,000 \mathrm{~L}\left(6 \mathrm{mg} \cdot \mathrm{mL}^{-1}\right)$. 
The final solution was kept under gentle magnetic stirring for $24 \mathrm{~h}$ at room temperature. After that, the resulting suspension was separated by centrifugation $\left(10,000 \mathrm{rpm} ; 4^{\circ} \mathrm{C}\right.$; $15 \mathrm{~min}$ ). The recovered pellet was washed once with $10 \mathrm{~mL}$ of distilled water containing $20 \%(v / v)$ of the corresponding cosolvent and twice with distilled water $(2 \times 10 \mathrm{~mL})$. Then, the suspension was directly lyophilized to obtain the catalyst in powder form for later use. The solid was characterized by TEM and XRD. The content of Pd in the solid was $25 \%$, determined by ICP-OES.

\subsection{Suzuki Reaction}

The aryl halide $(0.5 \mathrm{mmol})$ ( $0.051 \mathrm{~mL}$ of chlorobenzene, $0.053 \mathrm{~mL}$ of bromobenzene, or $0.059 \mathrm{~mL}$ iodobenzene) was added to a $1.5 \mathrm{~mL}$ screw-sealed vessel containing phenylboronic acid $5(0.067 \mathrm{~g}, 0.55 \mathrm{mmol}), \mathrm{NaOH}(0.03 \mathrm{~g}, 0.75 \mathrm{mmol})$ and, where indicated, the phase transfer catalyst (TBAF: $0.043 \mathrm{~g}, 0.165 \mathrm{mmol}$; TBACl: $0.046 \mathrm{~g}, 0.165 \mathrm{mmol}$; TBABr: $0.054 \mathrm{~g}, 0.165 \mathrm{mmol})$ in distilled water $(0.9 \mathrm{~mL})$. The mixture was kept at $50^{\circ} \mathrm{C}$ under strong magnetic stirring for $5 \mathrm{~min}$. After that, to initialize the reaction, the PdNPs biohybrids was added. The final suspension was left under vigorous magnetic stirring at $50{ }^{\circ} \mathrm{C}$ for the indicated times. The outgoing reaction was examined by the HPLC analysis of the reaction's samples withdrawn at different times. The analysis conditions were performed with a Kromasil-C4 $(150 \times 4.6 \mathrm{~mm}$ and $5 \mu \mathrm{m} ø)$, at a flow of $1.5 \mathrm{~mL} / \mathrm{min} ; \lambda: 254 \mathrm{~nm}$; and water:ACN (1:1) as the mobile phase: RT of the biphenyl product was 9 min. The yields were acquired extrapolating the values through a calibration curve of biphenyl $\left(R^{2}=0.9973\right)$.

\subsection{Heck Reaction}

Iodobenzene $(0.274 \mathrm{mmol}, 306 \mu \mathrm{L})$ and ethyl acrylate $(0.55 \mathrm{mmol}, 59 \mu \mathrm{L}$,) were dissolved in DMF or DMF/distilled water (final volume of $1 \mathrm{~mL}$ ). One $\mathrm{mg}$ of the hybrid $(0.25 \mathrm{mg}, 2.35 \mu \mathrm{mol}$ of Pd, $0.0085 \mathrm{~mol} \%$ of PdNPs) was added. The mixture was prewarmed at $70{ }^{\circ} \mathrm{C}$ below vigorous magnetic stirring for $5 \mathrm{~min}$. Next, to initialize the reaction, triethylamine ( $57 \mu \mathrm{L}, 0.412 \mathrm{mmol}$ ) was added. The final suspension was left under vigorous magnetic stirring at $70{ }^{\circ} \mathrm{C}$ for the indicated times. The outgoing reaction was monitored by the HPLC analysis of the reaction's samples withdrawn at different times. The analysis conditions performed were the same as in Section 2.4. The final product showed a RT of 6 min. The configuration was determined by HPLC using the (E) and (Z)-ethyl cinnamate standards.

\subsection{C-H Activation}

An amount of $0.192 \mathrm{mmol}(50 \mathrm{mg}$ ) of TrpOMe or benzene and $0.192 \mathrm{mmol}(42 \mathrm{mg})$ of MBDFB were added to a glass flask containing $5 \mathrm{~mL}$ of the solvent. The solution was left under magnetic stirring until homogenization. Then, $2 \mathrm{mg}$ of the PdNPs hybrid were added. The mixture was kept at room temperature for the indicated time. The outgoing reaction was monitored by the HPLC analysis of the reaction's samples withdrawn at different times. Samples $(100 \mu \mathrm{L})$ were centrifuged and then $50 \mu \mathrm{L}$ were diluted in $2 \mathrm{~mL}$ of bi-distilled water before the injection. The analysis conditions were achieved with a Kromasil-C8 $(150 \times 4.6 \mathrm{~mm}$ and $5 \mu \mathrm{m} ø)$, at a flow of $1.0 \mathrm{~mL} / \mathrm{min} ; \lambda: 270 \mathrm{~nm}$; and $50 \%(v / v)$ ACN in MilliQ water as the mobile phase.

\subsection{Enzymatic Hydrolysis of 4-Nitrophenyl Propionate ( $p N P P$ )}

The enzymatic activity in the biohybrid was evaluated spectrophotometrically measuring the increment in absorbance at $348 \mathrm{~nm}$ produced by the release of p-nitrophenol (pNP) $\left(\epsilon=5150 \mathrm{M}^{-1} \cdot \mathrm{cm}^{-1}\right)$ in the hydrolysis of $0.4 \mathrm{mM}$ pNPP in $25 \mathrm{mM}$ sodium phosphate at $\mathrm{pH} 7$ and $25^{\circ} \mathrm{C}$. To start the reaction, $50-200 \mu \mathrm{L}$ of the lipase solution or suspension were added to $2.5 \mathrm{~mL}$ of the substrate solution. The recovered enzymatic activity (\%) was obtained comparing the obtained values to the catalytic activity expressed by a $0.054 \mathrm{mg}$ $\mathrm{CAL}-\mathrm{B} / \mathrm{mL}$ water solution. 


\subsection{Transformation of 4-Nitrophenol ( $p N P$ ) to 4-Aminophenol ( $p A P$ )}

P-nitrophenol ( $\mathrm{pNP}$ ) was dissolved in $2 \mathrm{~mL}$ of distilled water at a $1 \mathrm{mM}$ concentration. Then, the solid $\mathrm{NaBH}_{4}(3.2 \mathrm{mg})$ was added to the solution. After this addition, the light-yellow solution changes to a strong yellow color, generating the formation of 4-nitrophenolate ions (substrate UV-peak undergoes to an immediate shift from 317 to $400 \mathrm{~nm}$ ). After $30 \mathrm{~s}, 3 \mathrm{mg}$ of the different Pd hybrids were added under gentle stirring at room temperature in an orbital shaker. The reaction progress was monitored by taking out an aliquot of the solution $(0.1 \mathrm{~mL})$ at different times, diluting it with distilled water $(2 \mathrm{~mL})$, and measuring the absorption spectrum between 500 and $300 \mathrm{~nm}$ in a quartz cuvette.

\subsection{Domino Synthesis of 4-Aminophenol ( $p A P$ ) from 4-Nitrophenyl Butyrate ( $p N P P$ )}

A solution of pNPP in ACN $(0.1 \mathrm{M} ; 0.25 \mathrm{~mL})$ was poured on a sodium phosphate buffer $\mathrm{pH} 7$ solution $(0.025 \mathrm{M} ; 2.25 \mathrm{~mL})$ and the mixture was under magnetic stirring at $25^{\circ} \mathrm{C}$ until homogenization. Next, the PdNPs-2 biohybrid was added. The reaction was kept on gentle stirring until complete conversion of pNPP to the product pNP (about $1 \mathrm{~h}$ ). Then, to initialize the Pd-catalyzed reduction of pNP to pAP, the solid $\mathrm{NaBH}_{4}(0.001 \mathrm{~mol}$; $0.0378 \mathrm{~g}$ ) was added straight to the reaction mixture under gentle magnetic stirring at $25^{\circ} \mathrm{C}$. The reaction progress was checked by taking out an aliquot of the solution $(20 \mu \mathrm{L})$, diluting it with water $(2 \mathrm{~mL})$, and measuring the absorption spectrum between 600 and $200 \mathrm{~nm}$ in a quartz cuvette.

\subsection{Dynamic Kinetic Resolution (DKR) of ( \pm )-1-Phenylethylamine}

Ethyl acetate $(6 \mu \mathrm{L}, 0.06 \mathrm{mmol})$ was added to $( \pm)$-1-phenylethylamine $(1.3 \mu \mathrm{L}, 0.01 \mathrm{mmol})$ in toluene $(1 \mathrm{~mL})$. The mixture was kept at $70{ }^{\circ} \mathrm{C}$ under vigorous magnetic stirring for $5 \mathrm{~min}$. After that, to initialize the reaction, $5 \mathrm{mg}$ of PdNPs-2 was added. The final suspension was left under vigorous magnetic stirring at $70{ }^{\circ} \mathrm{C}$ for the indicated times. The Pd-catalyzed racemization process was studied using s-phenylethylamine, as the substrate in the conditions described above. The reactions were monitored by the RP-HPLC analysis of the reaction's samples withdrawn at different times. The analysis conditions were column: Kromasil Ultrabase C18, $250 \times 4.6 \mathrm{~mm}, 5 \mu \mathrm{mø} ; \mathrm{f:} 1 \mathrm{~mL} / \mathrm{min} ; \lambda: 210$ and $254 \mathrm{~nm}$; mobile phase: $30 \%(v / v)$ ACN in MilliQ water $0.1 \%(v / v)$ trifluoroacetic acid; and temperature: $25^{\circ} \mathrm{C}$. The RT of phenylethylamine was $3.24 \mathrm{~min}$, whereas the RT of phenylacetamide product was $7.0 \mathrm{~min}$.

The enantiomeric excess (ee) value was determined by the chiral HPLC analysis of the reaction's samples withdrawn at a final time. The analysis conditions were: Phenomenex Lux Cellulose-1 $(250 \times 4.6 \mathrm{~mm}, 3 \mu \mathrm{m} ø)$ column, flow of $0.5 \mathrm{~mL} / \mathrm{min} ; \lambda: 210$ and $254 \mathrm{~nm}$; mobile phase: $10 \%(v / v)$ IPA in n-Hexane; and temperature: $25^{\circ} \mathrm{C}$. The RT of s-enantiomer was $24 \mathrm{~min}$, whereas the Rt of r-enantiomer was $26.5 \mathrm{~min}$. Before their injection, the different samples were diluted with the mobile phase and centrifuged for $10 \mathrm{~min}$ at $10 \mathrm{k} \mathrm{rpm}$. Each sample was injected in triplicate experiments.

\section{Results}

\subsection{Synthesis of Pd Nanoparticles Biohybrids Using C. antarctica B (CAL-B) Lipase}

The PdNPs biohybrids synthesis was performed in an aqueous medium by using a commercial liquid Candida antarctica B lipase (CAL-B). This enzyme was previously dissolved in distilled water $(0.5 \mathrm{mg}$ lipase $/ \mathrm{mL})$, and palladium acetate, previously dissolved in DMF $(1 \mathrm{mg} / \mathrm{mL})$, was added to this aqueous solution at room temperature and under gentle stirring. The total amount of DMF in the final solution was 20\% $(v / v)$. After 30 min, the initial clear solution turned to a slight cloudy suspension which was completely cloudy after $24 \mathrm{~h}$ of incubation. A solid was easily obtained after centrifugation which was washed with the same reaction solvent first, then distilled water, and finally frozen in liquid nitrogen and lyophilized, yielding the PdNPs-1 hybrid. No aggregation was observed in the enzyme solution without the Pd salt. 
An ICP-OES analysis of the supernatants after complete formation $(24 \mathrm{~h})$ revealed that around $7 \mu \mathrm{mol}$ of the $\mathrm{Pd}^{2+}$ amount was entrapped on the protein, whereas the protein determination by the Bradford method shows that $100 \%$ of the enzyme was in the heterogeneous hybrid. The thermo gravimetric analysis (TGA) of the lyophilized powder of PdNPs-1 (Figure 2A) showed that 26\% $(w / w)$ of the amount of Pd composed the solid material, confirming the value obtained previously by ICP-AES.

A

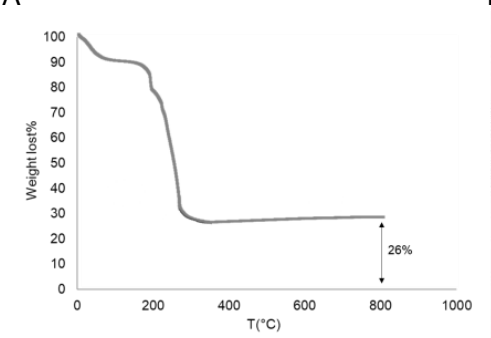

D

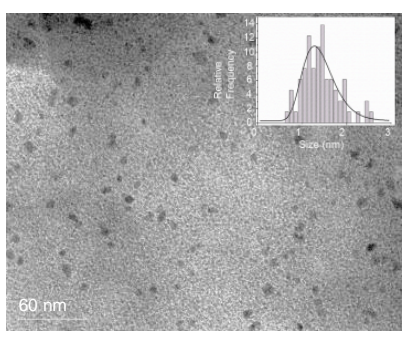

$\mathrm{B}$

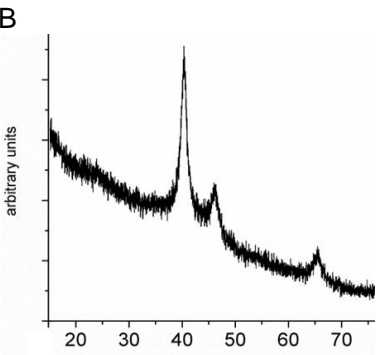

E

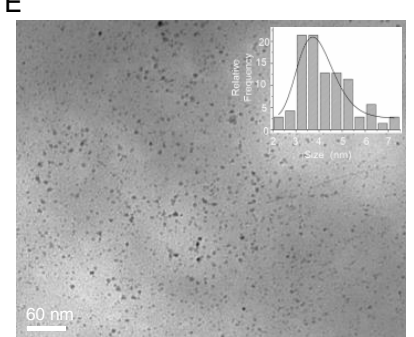

C

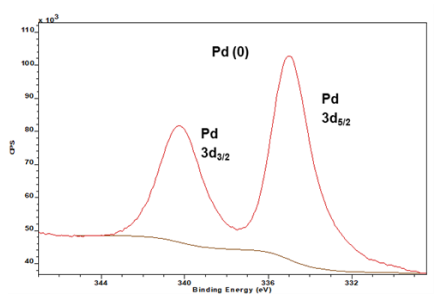

$\mathrm{F}$

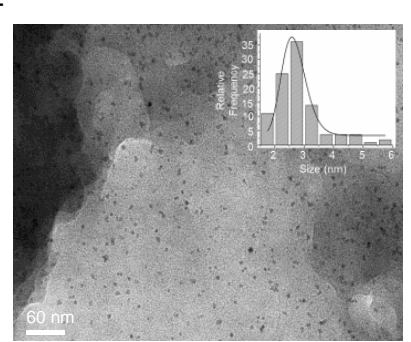

Figure 2. Characterization of the palladium-nanoparticles (PdNPs) biohybrids synthesized using CAL-B. (A) TGA of the PdNPs-1 biohybrid after $24 \mathrm{~h}$ of incubation. (B) XRD analysis. (C) XPS. (D) TEM image of PdNPs-1. (E) TEM image of PdNPs-2, (F) TEM image of PdNPs-3.

The X-ray analysis (XRD and XPS) demonstrated that the Pd(0) was the only metal species in the hybrid (Figure 2B,C). The TEM analysis confirmed the formation of principally small nanoparticles (PdNPs), with a diameter magnitude between 1-2 $\mathrm{nm}$ embedded in the protein net (Figure 2D).

To estimate the effect of the solvent in the Pd hybrid synthesis, the protocol was repeated dissolving the $\mathrm{Pd}$ salt in methanol or acetonitrile. These hybrids, PdNPs-2 (Figure 2E) and PdNPs-3 (Figure 2F), respectively conserved the bimodal distribution in NPs, although slight larger sizes $(2-3,3-4.5 \mathrm{~nm}$, respectively) were found.

These biohybrids were highly stable, without any changes in the particle size and morphology within 3 months in an aqueous solution or in a solid form at RT (data not shown). This offers an additional sign that the enzyme net acts as a stabilizing agent, as well as a physical support and reducing agent.

\subsection{Synthesis of Pd Nanoparticles Biohybrids Using Other Enzymes}

In order to ratify the effect of the enzyme, the synthesis of these PdNPs biohybrids was performed using two different lipases (Figure 3).

CAL-B has a particular characteristic, existing exclusively as a monomer in aqueous media, compared to other lipases, which normally exist mainly as a dimeric form [21]. 
A

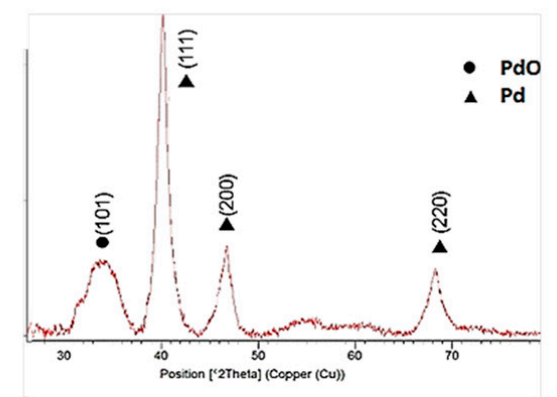

C

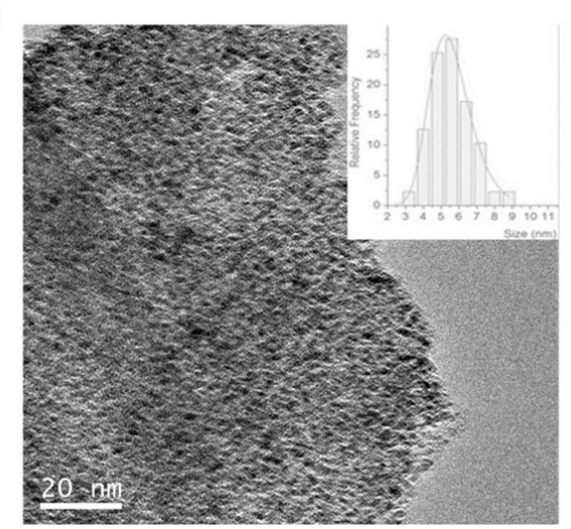

B

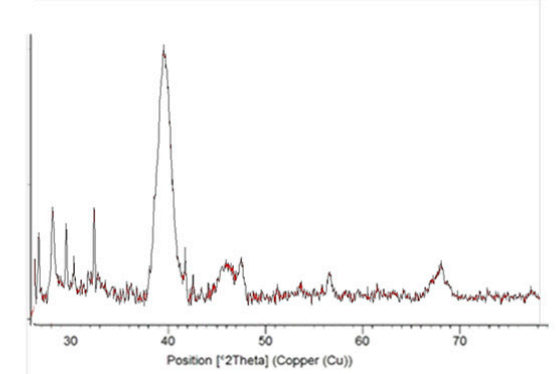

D

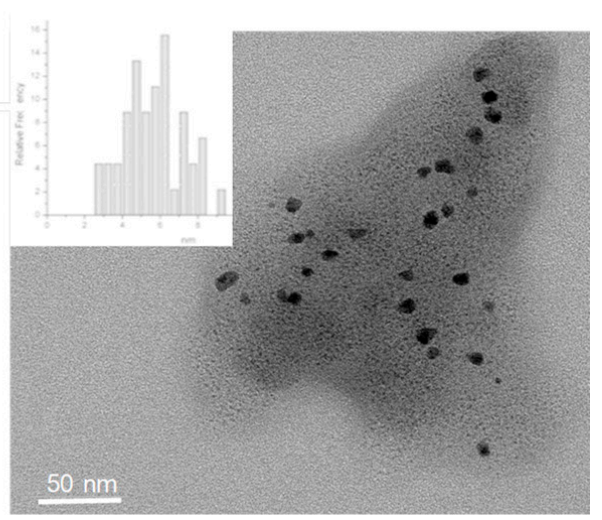

Figure 3. Characterization of hybrids with TLL and RML lipases. (A) XRD of PdNPs-4. (B) XRD of PdNPs-5. (C) TEM image of PdNPs-4 (inset particle size distribution). (D) TEM image of PdNPs-5 (inset particle size distribution).

In this phenomenon, the other lipases with a similar size [21] such as Rhizomucor miehei (Palatase) or Themomyces lanuginosus (TLL) have totally different behaviors.

Therefore, the effect of Pd nanoparticles formation using TLL was first evaluated. The protocol used in the synthesis was based on using methanol as a co-solvent for the synthesis, maintaining the same amount of protein per Pd. As previously with CAL-B, a solid was obtained, so called PdNPs-4. The ICP-OES analysis showed that the amount of Pd in this case was slightly higher (35\%). The XRD pattern surprisingly demonstrated that $\mathrm{Pd}(0)$ was not the only metal species, containing also $\mathrm{PdO}$ in this case (Figure $3 \mathrm{~A}$ ). The TEM analysis revealed that the PdNPs synthesized were 2-4 times larger than using CAL-B (Figure 3B).

When the synthesis was made using Palatase, similar results were found, a hybrid (PdNPs-5) with larger nanoparticle sizes (3-8 nm), in this case only of the metallic Pd.

Therefore, the use of the dimeric protein rather than the monomeric one affected the diameter size of the final Pd nanoparticles synthesized, but also of the Pd species.

\subsection{Application of PdNPs Biohybrids in C-C Bonding Formation}

\subsubsection{Suzuki Cross-Coupling Reaction}

The first application of these PdNPs biohybrids was in a well-known reaction catalyzed by palladium, the Suzuki cross coupling.

The PdNPs- 1 hybrid was tested as a catalyst in the Suzuki reaction against different aryl halides with phenylboronic acid at different conditions (Table 1). This catalyst was selected for the reaction, since it showed the smallest Pd nanoparticles. 
Table 1. Suzuki coupling of aryl halides with aryl boronic acid catalyzed by PdNPs biohybrids ${ }^{\text {a }}$.

\begin{tabular}{|c|c|c|c|c|c|}
\hline Hybrid & $X$ & PTC $^{c}$ & Base & Time (h) & Yield (\%) \\
\hline - & I & - & $\mathrm{NaOH}$ & 48 & 0 \\
\hline Enzyme & I & - & $\mathrm{NaOH}$ & 48 & 0 \\
\hline PdNPs-1 & $\mathrm{Cl}$ & - & $\mathrm{NaOH}$ & 48 & 2 \\
\hline PdNPs-1 & $\mathrm{Cl}$ & $\mathrm{TBABr}$ & $\mathrm{NaOH}$ & 48 & 1 \\
\hline PdNPs-1 & $\mathrm{Cl}$ & TBACl & $\mathrm{NaOH}$ & 48 & 2 \\
\hline PdNPs-1 & $\mathrm{Cl}$ & TBAF & $\mathrm{NaOH}$ & 48 & 1 \\
\hline PdNPs-1 & $\mathrm{Cl}$ & TBAF & $\mathrm{NaOH}^{\mathrm{d}}$ & 48 & 4 \\
\hline PdNPs-1 & $\mathrm{Cl}$ & TBAF & $\mathrm{K}_{2} \mathrm{CO}_{3}{ }^{\mathrm{d}}$ & 24 & 20 \\
\hline PdNPs-1 & I & - & $\mathrm{NaOH}$ & 24 & 55 \\
\hline PdNPs-1 & I & TBABr & $\mathrm{NaOH}$ & 38 & 50 \\
\hline PdNPs-1 & I & TBACl & $\mathrm{NaOH}$ & 34 & 51 \\
\hline PdNPs-1 & I & TBAF & $\mathrm{NaOH}$ & 38 & 52 \\
\hline PdNPs-1 & I & TBAF & $\mathrm{NaOH}^{\mathrm{d}}$ & 30 & 57 \\
\hline PdNPs-1 & I & - & $\mathrm{K}_{2} \mathrm{CO}_{3} \mathrm{~d}$ & 30 & 56 \\
\hline PdNPs-1 & $\mathrm{Br}$ & - & $\mathrm{NaOH}$ & 24 & 50 \\
\hline PdNPs-1 & $\mathrm{Br}$ & TBABr & $\mathrm{NaOH}$ & 5 & 99 \\
\hline PdNPs-1 & $\mathrm{Br}$ & TBACl & $\mathrm{NaOH}$ & 2.5 & $99(98)^{f}$ \\
\hline PdNPs-1 & $\mathrm{Br}$ & TBAF & $\mathrm{NaOH}$ & 10 & 96 \\
\hline PdNPs-1 & $\mathrm{Br}$ & TBACl & $\mathrm{NaOH}^{\mathrm{d}}$ & 48 & 97 \\
\hline PdNPs-1 & $\mathrm{Br}$ & TBACl & $\mathrm{K}_{2} \mathrm{CO}_{3}{ }^{\mathrm{d}}$ & 52 & 96 \\
\hline PdNPs-4 ${ }^{b}$ & $\mathrm{Br}$ & TBACl & $\mathrm{NaOH}$ & 24 & 45 \\
\hline
\end{tabular}

a Reaction conditions: Aryl halide $(0.5 \mathrm{mmol})$, phenylboronic acid $(0.55 \mathrm{mmol})$, base $(1.5 \mathrm{eq}), \mathrm{H}_{2} \mathrm{O}(1 \mathrm{~mL}), 0.13 \mathrm{mg}$ of catalyst, $50{ }^{\circ} \mathrm{C} .{ }^{b}$ Reaction conditions: Aryl halide $(0.05 \mathrm{mmol})$, phenylboronic acid $(0.055 \mathrm{mmol})$, base $(1.5 \mathrm{eq})$, $\mathrm{H}_{2} \mathrm{O} / 20 \%$ ACN $(1.2 \mathrm{~mL}), 1 \mathrm{mg}$ catalyst, $45^{\circ} \mathrm{C}$. ${ }^{\mathrm{c}}$ Phase transfer catalyst; $0.165 \mathrm{mmol}$; ${ }^{\mathrm{d}} 2$ eq base. ${ }^{\mathrm{e}}$ Calculated by the HPLC analysis. ${ }^{\mathrm{f}}$ Yield obtained after five cycles of the reused catalyst.

Initially, chlorobenzene was used as an aryl halide. Additionally, in most cases, with or without the presence of phase transfer catalysts (PTC), a different base, or increasing the equivalent, the biaryl synthesis was barely observed, with the best results obtained using $\mathrm{K}_{2} \mathrm{CO}_{3}(20 \%$ yield at $24 \mathrm{~h})$ (Table 1$)$. A clear enhancement was observed when the halide used was iodine. In this case, a 55\% yield of biphenyl was obtained, the value was not improved even using different PTCs or changing the base. Although it has been described that an extremely lower concentration of Pd in the commercial sodium carbonate could induce the biaryl formation in particular conditions [22], no conversion was observed when the reaction was performed without the catalyst or using a free enzyme (Table 1).

When the reaction was performed using bromobenzene, PdNPs-1 catalyzed the reaction producing $50 \%$ of biphenyl. However, in this case, the presence of the transfer catalyst improved the catalyst performance, obtaining full conversion in all cases. However, using TBACl, the quantitative yield of biphenyl was obtained in $2.5 \mathrm{~h}$ (Table 1). This PdNPs-1 hybrid was quite stable and was used during five reaction cycles without a significant activity loss after recovering (Table 1).

Moreover, in order to demonstrate the applicability for other biohybrids prepared with a different enzyme, the PdNPs-4 was used as a catalyst in the reaction with bromobenzene as aryl halide in an aqueous solution containing $20 \%$ acetonitrile and $45^{\circ} \mathrm{C}$. This catalyst produced $45 \%$ of biphenyl at these conditions after $24 \mathrm{~h}$ (Table 1 ).

These results represent an excellent example of the efficient catalysts in this C-C bonding reaction, as an alternative at different successful strategies, as recently described in [23-26]. 


\subsubsection{Heck Reaction}

A second C-C bonding reaction tested for the applicability of these biohybrids in organic synthesis was the Heck reaction (Table 2). In this case, the hybrids were first tested in a well described condition in the Pd-catalysis, using DMF as a solvent at $12{ }^{\circ} \mathrm{C}$. Pdbiohybrids exhibited an excellent catalytic activity and full conversion of iodobenzene and ethylacrylate in ethyl cinnamate was achieved after $24 \mathrm{~h}$ at these conditions (Table 2, entries $1-3)$. Decreasing the reaction $\mathrm{T}$ to $70{ }^{\circ} \mathrm{C}$ in DMF resulted in no conversion in any case.

Table 2. Heck coupling of aryl iodide with ethyl acrylate catalyzed by PdNPs biohybrids a ${ }^{\text {. }}$

\begin{tabular}{|c|c|c|c|c|c|}
\hline Entry & Catalyst & $\begin{array}{c}\text { Co-Solvent } \\
\left(\% v / v, \mathrm{H}_{2} \mathrm{O}\right)\end{array}$ & $\mathrm{T}\left({ }^{\circ} \mathrm{C}\right)$ & Time (h) & $\begin{array}{c}\text { Yield }^{b} \\
(\%)\end{array}$ \\
\hline 1 & PdNPs-1 & 0 & 120 & 24 & $>99$ \\
\hline 2 & PdNPs-2 & 0 & 120 & 24 & $>99$ \\
\hline 3 & PdNPs-3 & 0 & 120 & 24 & $>99$ \\
\hline 4 & PdNPs-3 & 0 & 70 & 24 & 0 \\
\hline 5 & PdNPs-3 & 25 & 70 & 18 & $>99$ \\
\hline 6 & PdNPs-3 & 50 & 70 & 24 & 20 \\
\hline 7 & PdNPs-2 & 25 & 70 & 18 & $>99$ \\
\hline 8 & PdNPs-1 & 25 & 70 & 18 & $>99$ \\
\hline
\end{tabular}

a Reaction conditions: Iodobenzene $(0.274 \mathrm{mmol})$, ethyl metacrylate $(0.55 \mathrm{mmol}), \mathrm{DMF}(1 \mathrm{~mL}), 1 \mathrm{mg}$ of catalyst, $70{ }^{\circ} \mathrm{C}$, triethylamine (TEA) $(0.412 \mathrm{mmol}){ }^{\text {b }}$ Calculated by the HPLC analysis.

However, the presence of a protein embedded in the Pd nanoparticles could confirm a more sustainable property to the hybrids, permitting their application in aqueous media. Therefore, we performed for the first time the Pd-catalyzed Heck reaction by adding water as a co-solvent.

The addition of $25 \%$ of water in DMF as the reaction media surprisingly permitted the PdNPs-3 to completely perform the C-C bonding reaction in $18 \mathrm{~h}$ at $70{ }^{\circ} \mathrm{C}$ (Table 2, entry 5). The addition of more amounts of water resulted in worse results, reducing the catalytic capacity of the PdNPs ( $20 \%$ yield in $24 \mathrm{~h}$ ). These results were also observed with the other hybrids, PdNPs-1 and PdNPs-2, yielding the product quantitatively after $18 \mathrm{~h}$ (Table 2, entries 7-8). No conversion was observed at these conditions when the reaction was performed without the catalyst or when using a free enzyme (data not shown).

These results demonstrate the potential applicability of these biohybrids in this C$\mathrm{C}$ bonding reaction, for example, in the production of more complex molecules, key intermediates in the drug synthesis was similar for other Pd nanocatalysts, as previously described in [27-29].

\subsubsection{C-H Activation}

Considering the excellent results obtained in the previous $\mathrm{C}-\mathrm{C}$ bonding formation, the direct $\mathrm{C}-\mathrm{H}$ reaction for arylation was attempted (Table 3 ). Initially, the experiments were performed by directly using benzene and aryl halide at different conditions using PdNPs-2 as a catalyst. Different conditions were used by changing aryl halide (I or Br), base, solvent, or T from 50 to $120^{\circ} \mathrm{C}$. However, in any case, the synthetic biaryl product was observed (Table 3, entries 1-6). In order to promote the reaction, a more active aryl donor was used, 4-methoxybenzenediazonium tetrafluoroborate (MBDFB). In this case, PdNPs-2 and PdNPs-4 were tested as a heterogeneous catalyst. 
Table 3. C-H arylation reaction catalyzed by PdNPs biohybrids.

\begin{tabular}{|c|c|c|c|c|c|c|c|}
\hline Entry & Catalyst & $\begin{array}{l}\text { Aryl- } \\
\text { Donor }\end{array}$ & $\begin{array}{c}\text { Aryl- } \\
\text { Acceptor }\end{array}$ & Solvent & $\mathrm{T}\left({ }^{\circ} \mathrm{C}\right)$ & Time (h) & $\begin{array}{c}\text { Conversion } \\
(\%)^{f}\end{array}$ \\
\hline $1^{a}$ & PdNPs-2 & 4-I-anisole & benzene & $\mathrm{DMF}^{\mathrm{b}}$ & 120 & 20 & 0 \\
\hline $2^{a}$ & PdNPs-2 & 4-I-anisole & benzene & $\mathrm{DMF}^{\mathrm{c}}$ & 120 & 20 & 0 \\
\hline $3^{a}$ & PdNPs-2 & 4-I-anisole & benzene & DMF & 50 & 5 & 0 \\
\hline $4^{\mathrm{a}}$ & PdNPs-2 & 4-I-anisole & benzene & $\mathrm{DMF}^{\mathrm{d}}$ & 120 & 20 & 0 \\
\hline $5^{a}$ & PdNPs-2 & 4-I-anisole & benzene & $\mathrm{DMSO}^{\mathrm{b}}$ & 50 & 5 & 0 \\
\hline $6^{\mathrm{a}}$ & PdNPs-2 & Br-benzene & benzene & Dioxane $^{\mathrm{d}}$ & 90 & 20 & 0 \\
\hline $7^{e}$ & PdNPs-2 & MBDFB & benzene & $\mathrm{MeOH}$ & r.t & 24 & 0 \\
\hline $8^{e}$ & PdNPs-2 & MBDFB & benzene & $\mathrm{MeOH} /$ Water & r.t & 24 & 0 \\
\hline $9^{e}$ & PdNPs-2 & MBDFB & benzene & THF & r.t & 24 & 0 \\
\hline $10^{\mathrm{e}}$ & PdNPs-4 & MBDFB & benzene & $\mathrm{MeOH}$ & r.t & 24 & 0 \\
\hline $11^{\mathrm{e}}$ & PdNPs-4 & MBDFB & benzene & $\mathrm{MeOH} /$ Water & r.t & 24 & 0 \\
\hline $12^{\mathrm{e}}$ & PdNPs-4 & MBDFB & benzene & THF & r.t & 24 & 0 \\
\hline $13^{e}$ & PdNPs-2 & MBDFB & TrpOMe & EtOAc & r.t & 16 & $>99$ \\
\hline $14^{\mathrm{e}}$ & PdNPs-2 & MBDFB & TrpOMe & THF & r.t & 16 & 36 \\
\hline $15^{\mathrm{e}}$ & PdNPs-2 & MBDFB & TrpOMe & Dioxane & r.t & 16 & 87 \\
\hline $16^{\mathrm{e}}$ & PdNPs-2 & MBDFB & TrpOMe & $\mathrm{MeOH}$ & r.t & 2 & $>99$ \\
\hline $17^{\mathrm{e}}$ & PdNPs-2 & MBDFB & TrpOMe & $\mathrm{EtOH}$ & r.t & 2 & 37 \\
\hline $18^{\mathrm{e}}$ & PdNPs-2 & MBDFB & TrpOMe & $\mathrm{MeOH} /$ water & r.t & 2 & $>99$ \\
\hline
\end{tabular}

a Conditions: $22 \mathrm{mmol}$ benzene, $0.5 \mathrm{mmol}$ 4-I anisole or Br-benzene, $15 \mathrm{mg}$ catalyst. ${ }^{\mathrm{b}}$ Potassium tert-butoxide $(0.75 \mathrm{mmol}) .{ }^{\mathrm{c}}$ Potassium tert-butoxide $(0.75 \mathrm{mmol}), \mathrm{K}_{2} \mathrm{CO}_{3}(1 \mathrm{mmol}) .{ }^{\mathrm{d}}$ Triethylamine (TEA) $(0.75 \mathrm{mmol}), \mathrm{K}_{2} \mathrm{CO}_{3}$ $(1 \mathrm{mmol}) .{ }^{\mathrm{e}}$ TrpOMe or benzene $(0.192 \mathrm{mmol}), \mathrm{MBDFB}(0.192 \mathrm{mmol})$, solvent $(5 \mathrm{~mL})$, catalyst $(2 \mathrm{mg})$, RT: Room temperature (c.a. $\left.20^{\circ} \mathrm{C}\right) .{ }^{\mathrm{f}}$ Conversion of the product was quantified by HPLC.

However, the reaction between the ionic liquid and 4-MeO-benzene was not produced even at different solvents, being only the metoxybenzene as a unique undesired product.

One interesting application consists of a site-specific modification of amino acids. Recently, some groups demonstrated the metal-catalyzed C-H arylation of the protected tryptophan using this ionic liquid [30,31].

Therefore, the PdNPs-2 hybrid was evaluated as a catalyst in the C-H activation of $\mathrm{N}$-acetyl-L-tryptophan methyl ester (TrpOMe) (Table 3). Initially, the reaction was tested in ethylacetate as a solvent, working well with a full conversion of the $\mathrm{C}-\mathrm{H}$ product at the C-2 position of the indol moiety in a Trp residue. The reaction was also tested in other water-soluble solvents, and surprisingly the reaction was extremely fast in pure methanol, with a full conversion in $2 \mathrm{~h}$. The efficiency of the catalyst in other solvents such as THF, dioxane, or ethanol was lower (Table 3, entries 14-17). Considering the previous results in the use of water in chemical reactions with this hybrid, the process was tested in $\mathrm{MeOH}$ :water 1:1. At these conditions, the Pd hybrid catalyst was as efficient as in the pure solvent (Table 3, entry 17).

Therefore, this example demonstrates again the versatility and sustainability of these PdNPs biohybrids in chemistry and represent an advantage strategy in terms of sustainability of the process comparison with the previous work [30-32].

\subsection{Application of PdNPs Biohybrids in Cascade Reactions}

After an evaluation of the high versatility of Pd chemistry of the nanohybrid, one of the advantages of this system is the conserved intrinsic enzymatic activity on the material. Therefore, these PdNPs biohybrids could be excellent for cascade processes.

In order to demonstrate that, first a domino reaction in the transformation of $\mathrm{p}$ nitrophenyl ester in p-aminophenol was attempted as a model reaction. The enzymatic hydrolytic activity and Pd reductive activity was evaluated (Table 4). 
Table 4. Dual (hydrolytic/reduction) activity of the PdNPs biohybrids for domino catalysis.

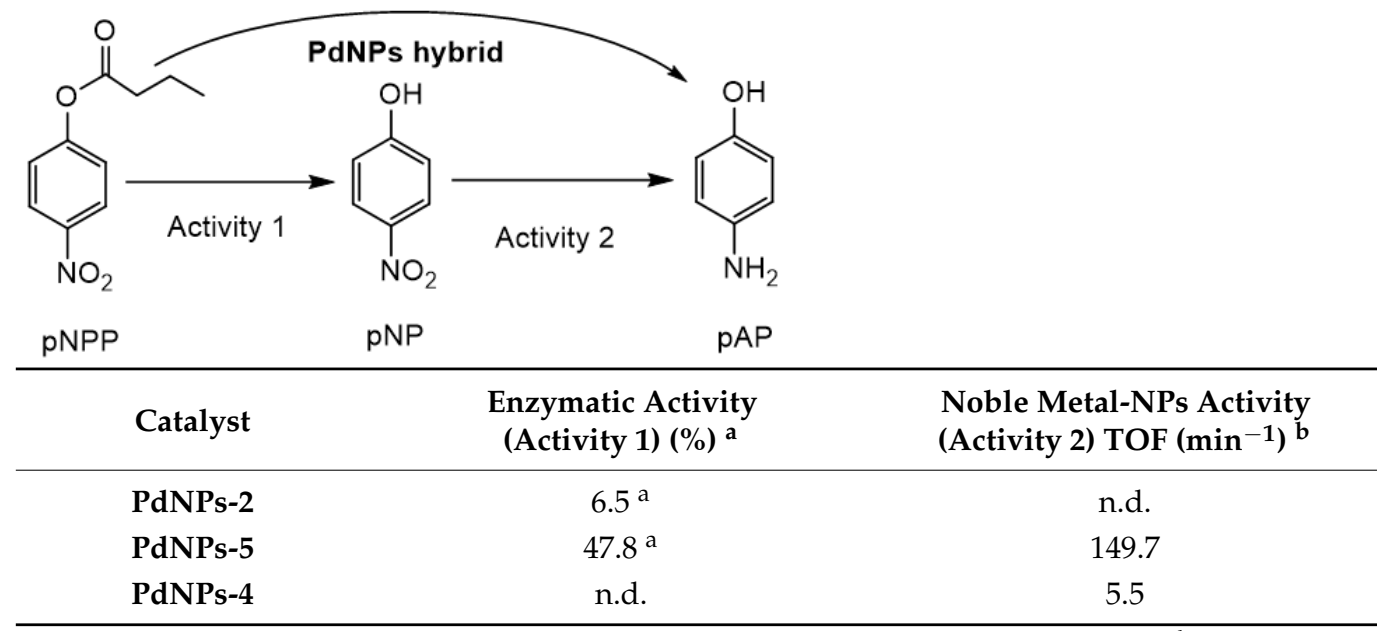

a Activity compared to the initial activity of CAL-B solution (100\%) in the absence of metal salts; ${ }^{\mathrm{b}}$ The TOF value was defined as the moles of p-aminophenol per mole of noble metal atoms in the PdNPs biohybrid per minute. n.d.: not determined.

PdNPs-2 showed the highest enzymatic activity (around 47\% activity in the hydrolysis of p-nitrophenyl propionate (pNPP compared to the soluble CAL-B) among the Pd nanohybrids. For the catalytic reduction of p-nitrophenol, the hybrid showed that the turnover frequency number (TOF) value $\left(>140 \mathrm{~min}^{-1}\right)$ was very interesting as other $\mathrm{Pd}$ catalysts developed for high yield production [33], whereas, for example, using the hybrid with TLL (PdNPs-4), the process was slower, demonstrating the effect of the nanoparticle size on the metal catalytic efficiency. The direct transformation of $10 \mathrm{mM}$ of pNPP to pAP was completely achieved using PdNPs-2 first, the activity in around $1 \mathrm{~h}$ with $0.08 \mathrm{mg}$ of the catalyst and just in $1 \mathrm{~min}$ by the simple addition of solid $\mathrm{NaBH}_{4}$ excess in the reaction mixture.

Finally, the capacity of these PdNPs biohybrids was attempted considering the production of enantiomerically pure products by the asymmetric catalysis.

In this case, the tandem catalysis by these hybrids (considering both the enzyme and $\mathrm{Pd}$ activity at the same time) was evaluated in the dynamic kinetic resolution (DKR) of rac-phenylethylamine. The soluble CAL-B was first used for studying the enzymatic transesterification, showing a very high enantioselectivity toward the R enantiomer (ee $>$ 99\%). PdNPs-2 was previously tested in the Pd-racemization of the enantiopure Sphenylethylamine. The enantiopure arylamine was totally converted to the rac mixture. Consequently, the tandem enzyme-Pd catalysis in the acetylation of rac-phenylethylamine, using ethylacetate as an acylation agent, was performed using PdNPs-2 in toluene at $70{ }^{\circ} \mathrm{C}$ (Table 5). The DRK worked perfectly, and an almost quantitative enantiopure Rphenylacetamide was obtained after $4 \mathrm{~h}$ at these conditions. The addition of bases in the process negatively affected the enantioselectivity of the product (Table 5).

\subsection{Recycling and Stability of the Heterogeneous Catalyst}

Furthermore, the Pd hybrid (PdNPs-2) was recycled in different reactions, as previously tested. This is quite interesting since the reactions were performed at different conditions; aqueous media and $50{ }^{\circ} \mathrm{C}$ (Suzuki), $70-120^{\circ} \mathrm{C}$ (DMF) or toluene and $70{ }^{\circ} \mathrm{C}$ (DKR), demonstrating the versatility of this heterogeneous catalyst.

In all cases, the catalyst was reused up to five times maintaining more than $95 \%$ of the metallic and, in this case, the enzymatic catalytic efficiency (Figure 4). After each cycle, the catalyst was washed with the same solvent used in the reaction and then the fresh reaction media was added for the next cycle. After the fifth cycle, the catalyst was analyzed by XRD and ICP demonstrating that the Pd species and the amount of metal did not change. 
Table 5. Dynamic kinetic resolution (( \pm )-1-phenylethylamine catalyzed by PdNPs biohybrids ${ }^{\text {a }}$.

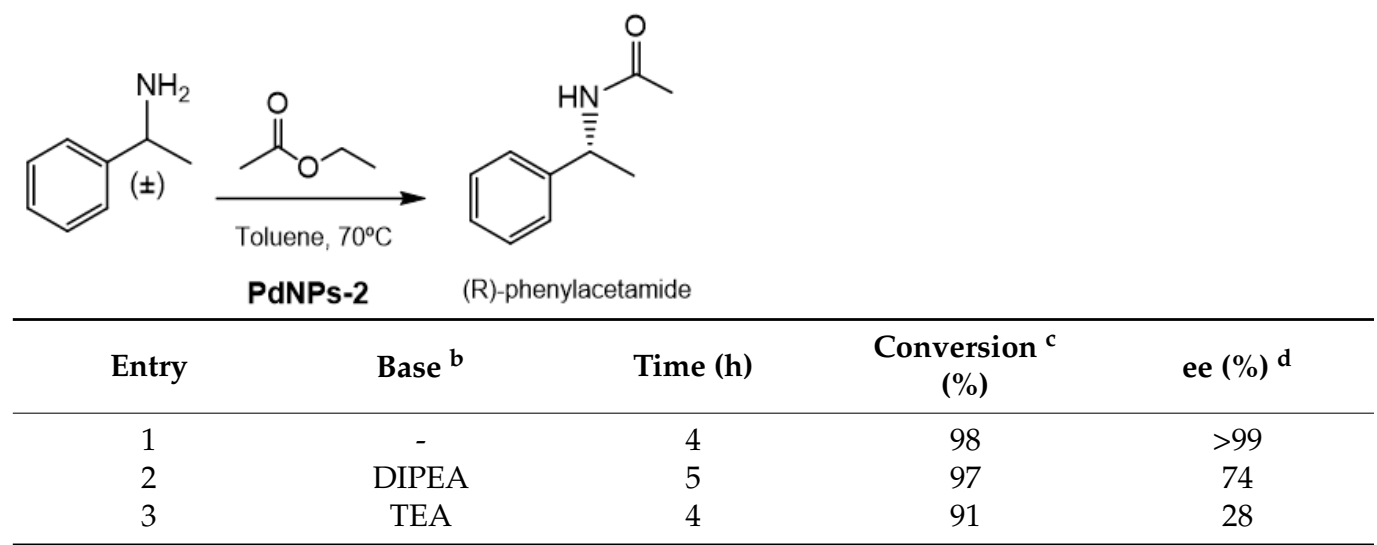

a Reaction conditions: Phenylethylamine $(0.01 \mathrm{mmol})$, ethylacetate $(0.06 \mathrm{mmol})$, toluene $(1 \mathrm{~mL})$ and $70{ }^{\circ} \mathrm{C}$, $5 \mathrm{mg}$ PdNPs-2. ${ }^{\mathrm{b}} 0.07 \mathrm{mmol} .{ }^{\mathrm{c}}$ Calculated by the RP-HPLC analysis. ${ }^{\mathrm{d}}$ Determined by the chiral HPLC. TEA: Triethylamine; DIPEA: N,N-diisopropylethylamine.

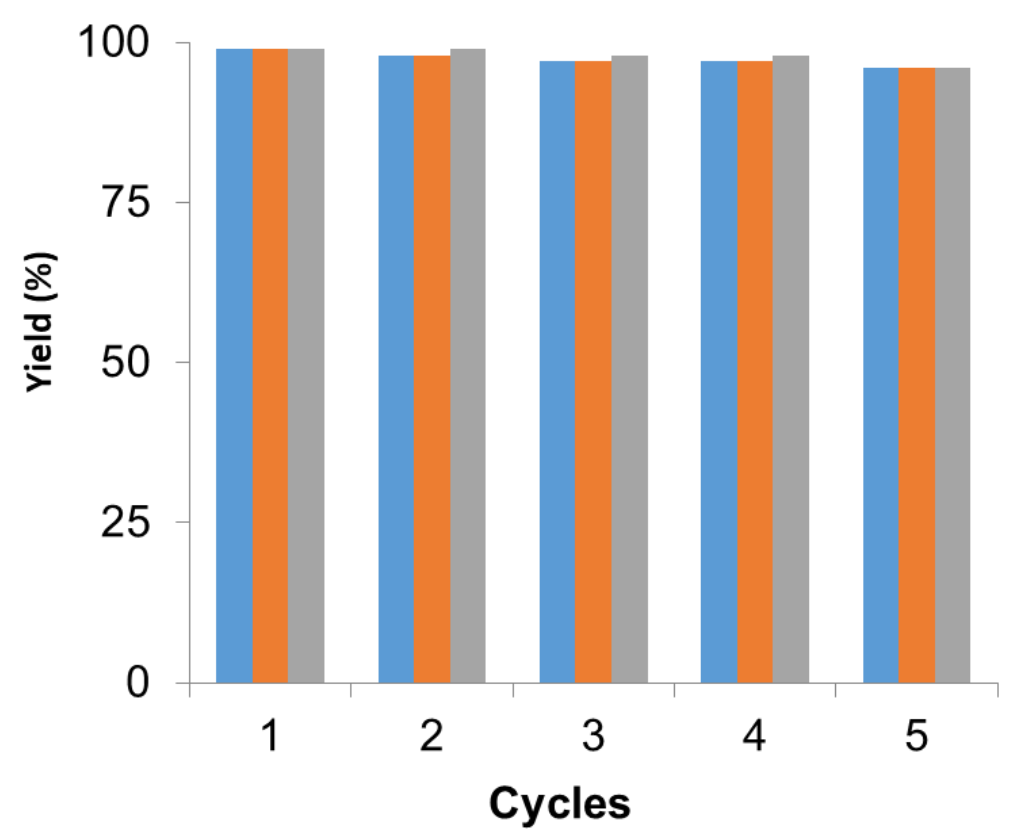

Figure 4. Recyclability of PdNPs-2 in the different reactions. Suzuki (blue), Heck (orange), dynamic kinetic resolution (DKR) (grey). Reaction conditions in each reaction were performed as previously described.

\section{Conclusions}

Here, we showed the straightforward preparation of highly stable palladium-nanoparticles (PdNPs) biohybrids at very mild conditions (aqueous media, room temperature, no reductive agents), based on the application of an enzyme, which induces the in situ formation of these small spherical nanoparticles on the protein network. We have demonstrated the effect of the enzyme scaffold in the nanoparticle size and the Pd species.

The excellent applicability in chemistry of these PdNPs biohybrids has been demonstrated with excellent versatility to work in an aqueous, aqueous/organic solvent, organic solvent, moderate to high temperature, in addition to the excellent results in the reduction and $\mathrm{C}-\mathrm{C}$ bonding reactions. Moreover, the cascade processes by dual activities of the hybrids have been demonstrated.

Therefore, these results open the possibility to easily combine together the desired enzyme and metallic catalytic activities for sustainable chemical processes. 
Author Contributions: M.F., N.L.-G., M.M., C.P.-R., and M.d.P.M. performed the experiments; J.M.P. designed and supervised the study and experiments; J.M.P. and N.L.-G. wrote the manuscript. All authors have read and agreed to the published version of the manuscript.

Funding: This work was supported by the Spanish Government, the Spanish National Research Council (CSIC). We also thank the Ministry of Education, Youth and Sports of the Community of Madrid, and the European Social Fund for a contract to C.P.-R. (PEJD-2017PRE/SAL-3762).

Institutional Review Board Statement: Not applicable.

Informed Consent Statement: Not applicable.

Data Availability Statement: Not applicable.

Acknowledgments: The authors thank Ramiro Martinez from Novozymes.

Conflicts of Interest: The authors declare no conflict of interest.

\section{References}

1. Fihri, A.; Bouhrara, M.; Nekoueishahraki, B.; Basset, J.M.; Polshettiwar, V. Nanocatalysts for Suzuki cross-coupling reactions. Chem. Soc. Rev. 2011, 40, 5181-5203. [CrossRef] [PubMed]

2. Li, H.; Guo, S.; Shin, K.; Wong, M.S.; Henkelman, G. Design of a Pd-Au Nitrite Reduction Catalyst by Identifying and Optimizing Active Ensembles. ACS Catal. 2019, 9, 7957-7966. [CrossRef]

3. Jin, Z.; Wang, L.; Zuidema, E.; Mondal, K.; Zhang, M.; Zhang, J.; Wang, C.; Meng, X.; Yang, H.; Mesters, C.; et al. Hydrophobic zeolite modification for in situ peroxide formation in methane oxidation to methanol. Science 2020, 367, 193-197. [PubMed]

4. Mun, Y.; Lee, S.; Cho, A.; Kim, S.; Han, J.W.; Lee, J.S. Cu-Pd alloy nanoparticles as highly selective catalysts for efficient electrochemical reduction of $\mathrm{CO}_{2}$ to CO. Appl. Catal. B Environ. 2019, 246, 82-88. [CrossRef]

5. Daniel, M.C.; Astruc, D. Gold nanoparticles: Assembly, supramolecular chemistry, quantum-size-related properties, and applications toward biology, catalysis, and nanotechnology. Chem. Rev. 2004, 104, 293-346. [CrossRef]

6. Wang, W.; Zhang, B.; Liu, Q.; Du, P.; Liude, W.; He, Z. Biosynthesis of palladium nanoparticles using Shewanella loihica PV-4 for excellent catalytic reduction of chromium(vi). Environ. Sci. Nano 2018, 5, 730-739. [CrossRef]

7. Veisi, H.; Ghorbani, M.; Hemmati, S. Sonochemical in situ immobilization of $\mathrm{Pd}$ nanoparticles on green tea extract coated $\mathrm{Fe}_{3} \mathrm{O}_{4}$ nanoparticles: An efficient and magnetically recyclable nanocatalyst for synthesis of biphenyl compounds un-der ultrasound irradiations. Mater. Sci. Eng. C 2019, 98, 584-593. [CrossRef]

8. Mohammadi, M.; Ghorbani-Choghamarani, A. 1-Methionine-Pd complex supported on hercynite as a highly efficient and reusable nanocatalyst for C-C cross-coupling reactions. New J. Chem. 2020, 44, 2919-2929. [CrossRef]

9. Xu, H.; Xiao, Y.; Xu, M.; Cui, H.; Tan, L.; Feng, N.; Liu, X.; Qiu, G.-Z.; Dong, H.; Xie, J. Microbial synthesis of Pd-Pt alloy nanoparticles using Shewanella oneidensis MR-1 with enhanced catalytic activity for nitrophenol and azo dyes reduction. Nanotechnology 2018, 30, 065607. [CrossRef]

10. Garole, V.J.; Choudhary, B.C.; Tetgure, S.R.; Borse, A.U.; Garole, D.J. Palladium nanocatalyst: Green synthesis, characterization, and catalytic application. Int. J. Environ. Sci. Technol. 2019, 16, 7885-7892. [CrossRef]

11. Sun, L.; Zhang, D.; Sun, Y.; Wang, S.; Cai, J. Facile Fabrication of Highly Dispersed Pd@Ag Core-Shell Nanoparticles Embedded in Spirulina platensis by Electroless Deposition and Their Catalytic Properties. Adv. Funct. Mater. 2018, 28, 1707231. [CrossRef]

12. Moghaddam, A.B.; Namvar, F.; Moniri, M.; Tahir, P.M.; Azizi, S.; Mohamad, R. Nanoparticles Biosynthesized by Fungi and Yeast: A Review of Their Preparation, Properties, and Medical Applications. Molecules 2015, 20, 16540-16565. [CrossRef]

13. Virkutyte, J.; Varma, R.S. Green synthesis of metal nanoparticles: Biodegradable polymers and enzymes in stabilization and surface functionalization. Chem. Sci. 2011, 2, 837-846. [CrossRef]

14. Smuleac, V.; Varma, R.; Baruwati, B.; Sikdar, S.; Bhattacharyya, D. Nanostructured Membranes for Enzyme Catalysis and Green Synthesis of Nanoparticles. ChemSusChem 2011, 4, 1773-1777. [CrossRef] [PubMed]

15. Benavente, R.; Lopez-Tejedor, D.; Palomo, J.M. Synthesis of a superparamagnetic ultrathin $\mathrm{FeCO}_{3}$ nanorods-enzyme bionanohybrid as a novel heterogeneous catalyst. Chem. Commun. 2018, 54, 6256-6259. [CrossRef] [PubMed]

16. Losada-Garcia, N.; Rodriguez-Otero, A.; Palomo, J.M. Tailorable synthesis of heterogeneous enzyme-copper nanobiohybrids and their application in the selective oxidation of benzene to phenol. Catal. Sci. Technol. 2020, 10, 196-206. [CrossRef]

17. Zhang, L.Y.; Han, F. Protein coated gold nanoparticles as template for the directed synthesis of highly fluorescent gold nanoclusters. Nanotechnology 2018, 29, 165702. [CrossRef]

18. Sheng, J.; Wang, L.; Han, Y.; Chen, W.; Liu, H.; Zhang, M.; Deng, L.; Liu, Y. Dual Roles of Protein as a Template and a Sulfur Provider: A General Approach to Metal Sulfides for Efficient Photothermal Therapy of Cancer. Small 2018, 14. [CrossRef]

19. Li, Y.; Song, K.; Cao, Y.; Peng, C.; Yang, G. Keratin-Templated Synthesis of Metallic Oxide Nanoparticles as MRI Contrast Agents and Drug Carriers. ACS Appl. Mater. Interfaces 2018, 10, 26039-26045. [CrossRef]

20. Filice, M.; Marciello, M.; Morales, M.D.P.; Palomo, J.M. Synthesis of heterogeneous enzyme-metal nanoparticle biohybrids in aqueous media and their applications in C-C bond formation and tandem catalysis. Chem. Commun. 2013, 49, 6876-6878. [CrossRef] 
21. Palomo, J.M.; Fuentes, M.; Fernández-Lorente, G.; Mateo, C.; Guisan, J.M.; Fernández-Lafuente, R. General trend of li-pase to self-assemble giving bimolecular aggregates greatly modifies the enzyme functionality. Biomacromolecules 2003, 4, 1-6. [CrossRef] [PubMed]

22. Arvela, R.K.; Leadbeater, N.E.; Sangi, M.S.; Williams, V.A.; Granados, P.; Singer, R.D. A reassessment of the transi-tion-metal free Suzuki-type coupling methodology. J. Org. Chem. 2005, 70, 161-168. [CrossRef] [PubMed]

23. Hooshmand, S.E.; Heidari, B.; Sedghi, R.; Varma, R.S. Recent advances in the Suzuki-Miyaura cross-coupling reaction using efficient catalysts in eco-friendly media. Green Chem. 2019, 21, 381-405. [CrossRef]

24. Mohazzab, B.F.; Jaleh, B.; Issaabadi, Z.; Nasrollahzadeh, M.; Varma, R.S. Stainless steel mesh-GO/Pd NPs: Catalytic applications of Suzuki-Miyaura and Stille coupling reactions in eco-friendly media. Green Chem. 2019, 21, 3319-3327. [CrossRef]

25. Soltani, S.S.; Taheri-Ledari, R.; Farnia, S.M.F.; Maleki, A.; Foroumadi, A. Synthesis and characterization of a supported Pd complex on volcanic pumice laminates textured by cellulose for facilitating Suzuki-Miyaura cross-coupling reac-tions. RSC Adv. 2020, 10, 23359-23371. [CrossRef]

26. Hong, K.; Sajjadi, M.; Suh, J.M.; Zhang, K.; Nasrollahzadeh, M.; Jang, H.W.; Varma, R.S.; Shokouhimehr, M. Palladium Nanoparticles on Assorted Nanostructured Supports: Applications for Suzuki, Heck, and Sonogashira Cross-Coupling Reactions. ACS Appl. Nano Mater. 2020, 3, 2070-2103. [CrossRef]

27. Parveen, N.; Sekar, G. Palladium Nanoparticles-Catalyzed Synthesis of Indanone Derivatives via Intramolecular Reductive Heck Reaction. Adv. Synth. Catal. 2019, 361, 4581-4595. [CrossRef]

28. Hajipour, A.R.; Khorsandi, Z.; Farrokhpour, H. Regioselective Heck reaction catalyzed by Pd nanoparticles immobili-zed on DNA-modified MWCNTs. RSC Adv. 2016, 6, 59124-59130. [CrossRef]

29. Baig, R.B.N.; Leazer, J.; Varma, R.S. Magnetically separable $\mathrm{Fe}_{3} \mathrm{O}_{4} @ D O P A-P d:$ A heterogeneous catalyst for aqueous Heck reaction. Clean Technol. Environ. Policy 2015, 17, 2073-2077. [CrossRef]

30. Reay, A.J.; Hammarback, L.A.; Bray, J.T.; Sheridan, T.; Turnbull, D.; Whitwood, A.C.; Fairlamb, I.J. Mild and regioselective Pd(OAc)2-catalyzed C-H arylation of tryptophans by [ArN2] X, promoted by tosic acid. ACS Catal. 2017, 7, 5174-5179. [CrossRef]

31. Lorion, M.M.; Kaplaneris, N.; Son, J.; Kuniyil, R.; Ackermann, L. Late-Stage Peptide Diversification through Cobalt-Catalyzed C- H Activation: Sequential Multicatalysis for Stapled Peptides. Angew. Chem. 2019, 131, 1698-1702. [CrossRef]

32. Potukuchi, H.K.; Bach, T. Selective C-2 alkylation of tryptophan by a Pd (II)/norbornene-promoted C-H activation reaction. J. Org. Chem. 2013, 78, 12263-12267. [CrossRef] [PubMed]

33. Shokouhimehr, M.; Hong, K.; Lee, T.H.; Moon, C.W.; Hong, S.-P.; Zhang, K.; Suh, J.M.; Choi, K.S.; Varma, R.S.; Jang, H.W. Magnetically retrievable nanocomposite adorned with Pd nanocatalysts: Efficient reduction of nitroaromatics in aqueous media. Green Chem. 2018, 20, 3809-3817. [CrossRef] 